\title{
CONVERBAL CONSTRUCTIONS IN SELKUP
}

\author{
Anja Behnke \\ University of Hamburg
}

\begin{abstract}
In Selkup, converbs and converbal constructions are extensively used in a wide range of different syntactic functions. However, the corpus data show significant differences regarding the frequency within the individual Selkup dialectal groups (Northern, Central and Southern). In Southern Selkup, converbal constructions occur more than three times more frequently than in Central and Northern Selkup. This southnorth divide can also be observed concerning some functions, especially complex predicates. The question arises why there is such a large difference in the frequency and which strategies Central and Northern Selkup use to express Southern Selkup converbal constructions.
\end{abstract}

Keywords: converbal constructions, complex predicate, Southern Selkup, Central Selkup, Northern Selkup, corpus, Turkic language contact

DOI: https://doi.org/10.12697/jeful.2020.11.2.06

\section{Introduction}

The term "Converbum" was first mentioned in Altaic studies by Ramstedt (1903) and was used to describe (Khalkha) Mongolian "halb verbale, halb nominale formen des verbums" (Ramstedt 1903: 55). Ramstedt associated the term with verbal nouns both historical and morphological, because "die khalkhassischen konverba auf ganz demselben Niveau wie diejenigen kasusformen der nominalen verbalformen [stehen], die als bestimmungen zum hauptverbum angewendet werden können"' (ibid.: 55). Later the term was adopted into a broader typological (European) context for "a nonfinite verb form whose main function is to mark adverbial subordination" (Haspelmath 1995: 3), i.e. a verbal adverb, as in example (1).

1 'The Khalkha Mongolian converbs are at the same level as those case forms of the nominal verbal forms which can be used as an adjunct to the main verb' (my translation, A.B.). 
(1) Italian (Haspelmath 1999: 1)

Non ave-ndo la chiave, non potè aprire. [not have-CvB the key] not could open

'Not having the key, she couldn't open.'

In this sense other scholars use the term converb synonymously with "gerund" (Latin, English), "adverbial participle" (Slavic), "deeprichastie" (Russian) and "gérondif" (French) (Tikkanen 2001, Haspelmath 1995) to cover a morphological category. The term is also used for converbal constructions as a syntactic structure which are polyfunctional and cover different syntactic and semantic functions. These include converbs as adjective attributes, free adverbials, in clausal subordination (example (1) above), in sequences of consecutive clauses ("clause-chaining", cf. Haspelmath 1995: 7), as in (2) and complex converbal predicates including motion events and converbal auxiliary constructions, as in example (3).

(2) Kumyk (Haspelmath 1995: 7-8)

Bu-lar, köl-nü gö-rüp, arba-syn toqtat-yp, čemodan-ny this-PL lake-ACC see-CVB cart-3sG stop-CVB suitcase-ACC Manaj-ğa da göter-t-ip, köl-nü jağa-syn-a Manaj-DAT also take-CAUS-CVB lake-GEN bank-3SG-DAT bar-yp, čemodan-ny ač-yp, šišla-ny, čy̆grar-yp go-CVB suitcase-ACC open-CVB bottle-ACC take.ouT-CVB tiz-ip suw-dan toltur-up, qajtar-yp put.in.row-CVB water-ABL fill-CVB return-CVB čemodan-ğa sal-a. suitcase-DAT put-RES 'They see the lake, stop their cart, make Manaj bring the suitcase, go to the bank of the lake, open the suitcase, take out the bottles, put them in a row, fill them with water, and put them back into the suitcase.'

(3) Kamas (Klumpp 2002: 217)

$\begin{array}{llrl}\check{s} u t & k u \text { 'ptōlaga } & {[k u \text { ?bdolaga }<k \text { ku’bdola(?) }} & \text { ige }] . \\ \text { fire.3SG } & \text { extinguish.IPF.PRS } & \text { extinguish-CVB } & \text { be.PRS }\end{array}$

'His fire is extinguishing.' 
Thus, the term converb is ambiguously used for a wide range of functions that are also covered by other nonfinite forms (infinitive, participle). Converbs are described for a number of Uralic languages, among others, Khanty (Fil'chenko 2010: 470), Udmurt (Horváth 2013, Winkler 2011, Pischlöger 2001, Kel'makov 1975), Mari (Bradley 2016a, Isanbaev 1978), Nenets (Nikolaeva 2014, Stenin 2010, Pischlöger 2001: 47, Décsy 1966: 50-51), Enets (Shluinsky 2018, Siegl 2013: 325), Nganasan (Wagner-Nagy 2019, Katzschmann 2008, Tereščenko 1979) and Kamas (Klumpp 2005, 2002). In the present article other nonfinite forms are not taken into account.

Complex converbal predicates are typical in Turkic languages (Bradley 2016a: 130-131), but atypical in Finno-Ugric languages and analysed as structural borrowings from Turkic languages in Udmurt (Horváth 2013, Winkler 2011, Kel'makov 1975), Mari (Bradley 2016a, Isanbaev 1978) and Kamas (Klumpp 2005, 2002).

Selkup converbs and partly also converbal constructions are mentioned in different grammatical descriptions: Voevodina 1976, Kuznecova et al. 1980, Helimski 1983, Helimski 1998, Čeremisina and Martynova 1991, Kuznecova 1995, Valijärvi 2008. Mostly simple converbs (ending in -le) are distinguished from complex ones (ending in -pūle, Northern Selkup, or -lewle, Central and Southern Selkup). It is partly assumed that simple converbs are used to express simultaneity while complex converbs express non-simultaneity. It follows that Selkup converbs are considered from a morphosyntactic perspective. Furthermore the major part of descriptions is based on data from Northern Selkup dialects (Kuznecova et al. 1980, Valijärvi 2008). Central and Southern Selkup converbs are described only briefly by Helimski (1983) and Čeremisina and Martynova (1991). In Kuznecova's monography (Kuznecova 1995), Southern Selkup converbal constructions are also mentioned. She concentrates, however, on a morphological description and the etymology of the converbal form(s).

The occurence of converbs as a part of complex predicates (see Section 3.1) is also mentioned in the Selkup research literature, however, a detailed and systematic analysis and classification lacks so far. To close this gap the present article will consider converbal constructions similar to Mari, Udmurt and Kamas. Other functions are not discussed in the remainder of the paper. 


\section{Corpus}

The present article is based on language material of the Selkup Language Corpus developed at the University of Hamburg (Budzisch et al. 2019). The corpus contains 144 already published texts from Northern, Central and Southern Selkup, as well as from a mixed dialect which has characteristics of both Central and Southern dialects (see Table 1 below).

Table 1. Central and Southern Selkup dialects ${ }^{2}$

\begin{tabular}{ll}
\hline Central Selkup & Southern Selkup \\
\hline Vakh & Middle Ob \\
Tym & Upper Ob \\
Vasyugan & Ket \\
Narym & Chaya \\
& Chulym $(\dagger)$ \\
\hline
\end{tabular}

Texts were recorded in a period of about 130 years (see Table 2). The texts are mostly folklore and narratives, but also some translations of Russian texts exist. All texts are consistently glossed and annotated. Each text has an individual name composed of the pattern name_year title_genre (name=initials of the speaker, year=year of recording, title $=$ short English name, genre=flk [folklore], nar [narrative], trl [translation] or song [heroic song]). The examples used in the present article contain also the sentence number, the dialect and the original Russian translation, if applicable. Since Selkup is predominantly a spoken language the corpus texts represent oral language and thus also a broad dialectal variation. This means that both suffixes and lexemes can occur in very diverse forms.

Table 2. Selkup Language Corpus

\begin{tabular}{ccccc}
\hline & Northern & Central & mixed & Southern \\
\hline texts & 26 & 48 & 4 & 66 \\
units & 1,410 & 3,196 & 630 & 4,021 \\
tokens & 9,257 & 22,014 & 1,453 & 22,525 \\
\hline
\end{tabular}

2 Following Gluškov and Bajdak (2016). 


\section{Converb vs. converbal construction}

Selkup verbal morphology shows two different converbal suffixes: a simple one ending in -le and a complex one -le püle consisting of the simple converb -le and the converbal form of the verb $p \bar{u}$ 'cross' pūle (Kuznecova et al. 1980: 256 ff., Helimski 1983: 46, Čeremisina and Martynova 1991: 36, Kuznecova 1995: 195-196, Valijärvi 2008: 169 ff.). The latter one is used in the forms -lewle, -l(e)bele, -lebe, -lepe(le), -ple in Central and Southern Selkup. In the following examples, the simple and complex converbal forms are glossed with CVB.I for simple and CVB.II for complex ones.

Both converbal forms can occur in different syntactic functions: (i) free adverbial, as in (4); (ii) usage in sequences of several consecutive clauses ${ }^{3}$, as in (5); (iii) usage in dependent situations with different readings, as the temporal one in (6); (iv) part of complex predicates with various types (see Section 3.1). The following sections will focus on complex converbal predicates.

\begin{tabular}{|c|c|c|c|c|}
\hline $\begin{array}{l}k u d=n e j \\
\text { who=EMPH }\end{array}$ & $\begin{array}{l}\text { qwesse } \\
\text { back }\end{array}$ & $\begin{array}{l}\text { ili-l'e } \\
\text { live-CVB.I }\end{array}$ & $\begin{array}{l}\text { ass } \\
\text { NEG }\end{array}$ & $\begin{array}{l}\text { para-l-ba- } n . \\
\text { return-RES-PST.REP-3SG }\end{array}$ \\
\hline \multirow{2}{*}{\multicolumn{5}{|c|}{$\begin{array}{l}\text { ‘Никто живой обратно не возвращался.' } \\
\text { 'No one returned alive.' }\end{array}$}} \\
\hline & & & & \\
\hline
\end{tabular}

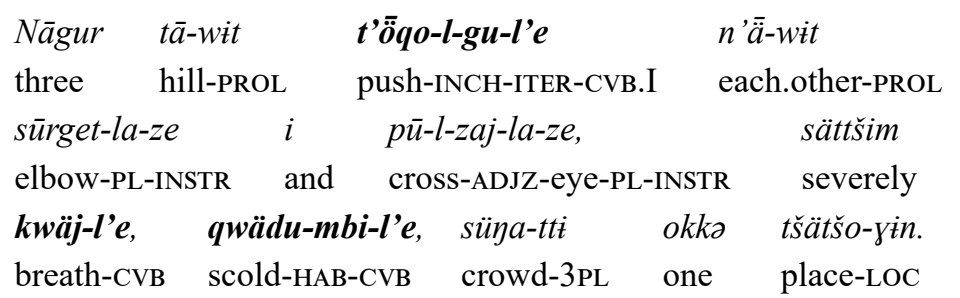

' $B$ се трое, толкая друг друга локтями и коленями, пыхтя и ругаясь, толкутся на одном месте.

'The three push each other up to the hill, with elbows and knees, breathing heavily, arguing, were in one place.'

(KMS_1968_Burbot_trans_98, S: Middle Ket')

3 Haspelmath (1995: 7) uses the term clause-chaining. 
(6) Awi-t, $\quad \begin{aligned} & \text { azi-t } \\ & \text { mother-3sG father-3sG fish-TR-CVB.II }\end{aligned}$
'Мать её, отец её с рыбалки пришли.'
'Her mother (and) her father came after fishing.'
(ILP_1981_ItjaOneEyedDevil_flk_10, S: Middle Ob)

\subsection{Complex predicates}

In the following section four subtypes of complex converbal predicates are described. The classification is based on preliminary studies. With a few minor exceptions, the converbal form regularly precedes the finite verb form. ${ }^{4}$ More and detailed analysis is needed to develop an adequate classification of finite verb forms in Selkup converbal constructions. However, the preliminary classification is as follows.

\subsubsection{Type A}

Type A consists of a lexical verb in a converbal form and one of the phasal verbs oldə- 'begin', kwatta 'begin', übə- 'begin', malč z- 'finish', mančz- 'finish' as the finite part. Typically the converbal form precedes the finite verb form.

In Southern Selkup examples of all phasal verb forms except for mančz- 'finish' can be found in the corpus. They are almost exclusively used with converbs. Examples (7) to (9) show the different phasal verbs 'begin', and in (10) malčs- 'stop' is paired with the converbal form of aur- 'eat'.

\begin{tabular}{|c|c|c|c|}
\hline pоэqә-m & inne & $\overline{\ddot{u}} q \partial-l l e$ & ïpo-r-o-t. \\
\hline net-ACC & up & drag-CVB.I & begin-FRQ-EP-3SG.O \\
\hline
\end{tabular}

'Он начинает вытаскивать сеть из воды.'

'He begins to drag the net up.'

(NN_1879_Itja_flk_43, S: Chaya)

4 Complex converbal predicates reflects the typical Selkup modifier-head-order. Possible variations in word order between the individual subtypes have to be analysed in future research. 
(8)
pōne-la-n
pal'd'u-l'e oldi-y.
outside-PL-LOC.ADV go-CVB.I
begin-3sG

'На улице ходить начал.'

'He starts going outside.'

(KMS_1966_TwoSisters_flk_77, S: Middle Ket')

(9)
Lōz-la tōomba-t
i kozir-č-le
kwatta-ľ̆a-t.
devil-PL come-PST.REP-3PL and card-TR-CVB.I begin-INT.PF-3PL

'Черты пришли и начали играть в карты.'

'Devils came and begin to play cards.'

(SEV_1981_SisterBrother_flk_38, S: Middle Ob)

(10) Aur-le malčă-ga.

eat-CVB.I stop-3DU.S

'Наелись.'

'They stop eating.'

(PVD_1961_FarmAssault_flk_146, S: Upper Ob)

There are a handful of examples using infinitives instead of converbs, mostly from translations of Russian texts. In these cases the infinitive consistently follows the finite verb form.

In the mixed dialect group examples of kuatta- 'begin' and one example of malče- 'stop' is documented. All converbal forms immediately precede the finite verb form, as in (11).

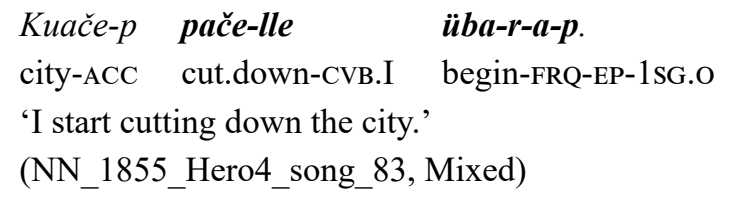

Not many examples of phasal verbs are to be found in Central Selkup. Only mančz- 'finish' in (12a) and qwatti- 'begin'5 in (12b) occur in converbal constructions.

5 Except for one example in a translated text, qwatti- is only used with converbs. 

a. Tabo ǚ̌ $u-k u-k$,
$\overline{\boldsymbol{u}} \boldsymbol{z} \boldsymbol{\partial}$-le
man-rrēe-špa-t,
$3 \mathrm{SG} \quad$ work-ITER-3SG
work-CVB.
finish-FRQ-EP-IPFV-3SG.O
uboršicā-n
tēntra
pōne-t
mēkka
female.cleaner-DAT/ALL speak.3sG
outside-LOC.ADV 1SG.DAT
qwā-gu, ku-n'ibet pad'̄ mozno?
go away-INF where-any just one.can
'Он работает свою работу кончает и уборщицу спрашивает:
«На улицу мне сходить куда-нибудь можно?»
'He finishes his work and says to the female cleaner: Can I go anywhere outside now?'
(SDP_1964_FairytaleBlackZar_flk_376, C: Narym)

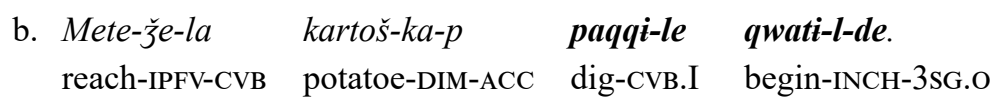
'Дошла, картошку начала копать.'
'He comes there, starts digging for potatoes.'
(SDP_1964_FairytaleBlackZar_flk_835, C: Narym)

In all other examples phasal verbs are used with infinitives and show the phasal verb 'begin' in the forms lakki-, titi- or qwatti-. In most cases the finite verb form precedes the infinitive, as in (13a). In all examples from the Vasyugan subdialect and in the only example from the Tym subdialect, the finite verb forms follows the infinitive, as in (13b) and (13c).
a. Nä-l-gup
ando-ute
paht-r-a
aj
woman-ADJZ-person
boat-PROL
jump-FRQ-AOR.3sG
and
titi-ži-mba
pă̌a-le-šp $\varepsilon-g u$.
begin-IPFV-PST.REP.3SG
chop-INCH-IPFV-INF
'Женщина из лодки выпрыгнула и стала рубить.'
'The woman jumped out off the boat and began to chop [the trees].' (KIA_2014_KatManPuch_trans_40, C: Narym)
b. Tab ku-d-e-n
kwen-gu
laka-tte-ku-k,
$3 \mathrm{SG}$ person-PL-EP-DAT/ALL go.away-INF begin-IPFV-ITER-3SG
Id'e $k u-d-e-n \quad$ aya üdi-ld'e,
Itja person-PL-EP-DAT/ALL NEG send-INT.PF.3SG
pokko-m-de ora-l-lad'e.
net-ACC-3SG hold-INCH-INT.PF.3SG 
'Он к людям идти только захочет, мезгирь к людям не пускает, сетью его поймает.'

'If he wants to go to the people, Itja does not let him go, he catches him with the net.'

(ChDN_1983_ItjasTown_flk_16, C: Vasyugan)

c. Kušā-göt tat lēma-p mēe-gu kuöttā-ľ̆a-l,

when-LOC 2SG board-ACC do-INF begin-INT.PF-2SG.O

to tärbe-š manžö-gu kaj-l-žön $\bar{e}-m a$.

then think-IMP.2SG look-INF what-ADJZ-DRV be-COND.3sG

'Когда ты начинаешь какое-либо дело, то обдумай, как его надобно кончить.'

'If you begin to make something, then think about how to end it.'

(KAO_1912_SmartPeople_trans_8, C: Tym)

In Northern Selkup there is only one example in the corpus containing a converb and the phasal verb $\bar{u} k \dot{t}$ - 'begin', as in (14a). The only other phasal verb in the corpus is olam- 'begin'. It appears always in infinitive constructions where the infinitive of the lexical verb is melted with the finite form of olam-, as in (14b).

a. Qum-i-t ami-r-lä üki-talth-tit.

person-EP-PL eat-FRQ-CVB.I begin-DRV-3PL

'Люди кушать начали.'

'The people start eating.'

(BVP_1973_East_flk_42, N: Taz)

b. Nini ili-q-olam-n̄-tit.

then live-INF-begin-AOR-3PL

'Потом жить стали (они-многие).'

'Then they start to live.'

(BIV_1941_KonMytyke_flk_34, N: Taz)

\subsubsection{Type B}

Type B consists of a lexical (motion) verb in a converbal form and a second motion verb, whereby the converb expresses the manner of motion (go, fly, run ...) and the finite verb expresses the path. In Talmy 
(2007) these structures, which indicate the path with the main verb, are called verb-framed, in contrast to satellite-framed structures, which express the path preferably by a satellite of the verb (Talmy 2007: 153). The first type is typical of Turkic but atypical of Finno-Ugric languages (Talmy 2007: 72, Slobin 2000: 109). Bradley extends the allocation to all Uralic languages (Bradley 2016b: 126), but in all Samoyedic languages verb-framed motion events appear (not only under Turkic influence as postulated by Bradley). In (15a) to (15c) the path is included in the finite verb form, the manner of motion is not overtly expressed but is included in the context.

(15) a. Forest Enets (Siegl 2013: 170)

Nääku-ju-xo minxuda očik liđi-ru-ku-je
other-TOP-INDEF suddenly bad bone-LIM-DIM-PEJ
minxuda odi-ma go.out-RES.3sG outside-LAT.SG
suddenly suddenly, the little bad bony guy came out.'
'The other one, sudde

b. Tundra Nenets (Nikolaeva 2014: 374)

\begin{tabular}{|c|c|c|}
\hline $\begin{array}{l}\text { Xas }{ }^{\circ} \text {-xəna } \\
\text { low.tide-LOC }\end{array}$ & $\begin{array}{l}\text { to-wewaq } \\
\text { come-PERF.PART.1PL }\end{array}$ & $\begin{array}{l}\eta \bar{c}-b^{\circ} q-n a q \\
\text { be-COND-1PL }\end{array}$ \\
\hline$y a w-{ }^{\circ} h$ & $m^{\prime} u h$ & $n^{\prime} i$-wewaq \\
\hline sea-GEN & lake-GEN & NEG-INFR.1PL \\
\hline
\end{tabular}

'If we had come when the tide is low, we wouldn't have entered this bay.'

c. Nganasan (Wagner-Nagy 2019: 235)

ya-laa ma-to čii-?ə.
mouth-LIM tent-LAT come.in-AOR.3sG
'The storyteller entered the tent.'

Most examples of type B are from one of the Southern Selkup dialects (see Table 3 for an overview of all combinations), as in example (16).
Aba- $t$
kur-l'e t'ü-a-n,
k'ed'egu-m t'abo-t.
old.sister-3SG run-CVB.I come-AOR-3SG basket-ACC catch-3sG.O
'Старшая прибежала, кузов схватила.'
'Her older sister comes running to get the basket.'
(PMP_1961_ForestWoman_flk_123, S: Middle Ob) 
Table 3. Combinations of motion verbs in Southern Selkup

\begin{tabular}{|c|c|}
\hline Converb & Finite verb \\
\hline $\begin{array}{l}\text { tö- 'come', tayz- 'crawl', qwan- 'go away', wässa, } \\
\text { timbi- 'fly', } \bar{u} t \partial-\text { 'send, let go', } \bar{u} \text { - 'swim' }\end{array}$ & medi- 'reach' \\
\hline $\begin{array}{l}\text { timbi- 'fly', qwaja- 'go', tudi- 'reach', kur- 'run', } \\
\text { üto- 'send, let go' }\end{array}$ & $t \bar{o}-$ 'come' \\
\hline qwetz- 'catch', tö̈- 'come', kur- 'run', tita- 'walk' & 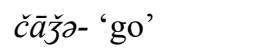 \\
\hline tanyə- 'crawl', mendi- 'pass through' & qo- 'go' \\
\hline $\begin{array}{l}\text { pū- 'cross', čanže- 'go out', laqqa- 'move, work', } \\
\text { tita- 'walk' }\end{array}$ & qwan- 'go away' \\
\hline čačt- 'leave' & kwedi- 'leave' \\
\hline sape- 'spring out' & čaร̌e- 'run' \\
\hline tangi- 'throw out', $\bar{u}$ - 'swim' & üta- 'send, let go' \\
\hline
\end{tabular}

In all heroic songs from the mixed dialect examples of type B can be found, as in (17a) and (17b). The analysed combinations are listed in Table 4 below.
a. Ku-la-m
pone čanక̆e-le
kuan-na-det.
person-PL-1sG outside go.out-CVB.I go.away-AOR-3PL
'My people went outside.'
(NN_1855_Hero3_song_309-310, Mixed)
b. Nat.kund keba kuene-k
(NN_1855_Hero2_song_377-378, Mixed)
kur-a-lbele tö-k.
there.long small brother-in-law-DIM run-EP-CVB.II come-3sG
'Meanwhile the small brother-in-law comes running.'

Table 4. Combinations of motion verbs in the mixed dialect

\begin{tabular}{|c|c|}
\hline Converb & Finite verb \\
\hline tö- 'come’ & medi- 'reach' \\
\hline kur- 'run' & tö- 'come’ \\
\hline tö- 'come', qwan- 'go away' & alče- 'fall' \\
\hline para- 'return', tȫ- 'come' & čaร̌e- 'go' \\
\hline čanక̌e- 'go out', para- 'return' & qwan- 'go away' \\
\hline qoja- 'surround' & čanక̌e- 'go out' \\
\hline
\end{tabular}


In Central Selkup texts only one speaker from the Narym subdialect uses motion verbs in converbal constructions. Table 5 gives an overview of all attested combinations. All examples are translations from Russian. The converbal form always precedes the finite verb form, as in (18).

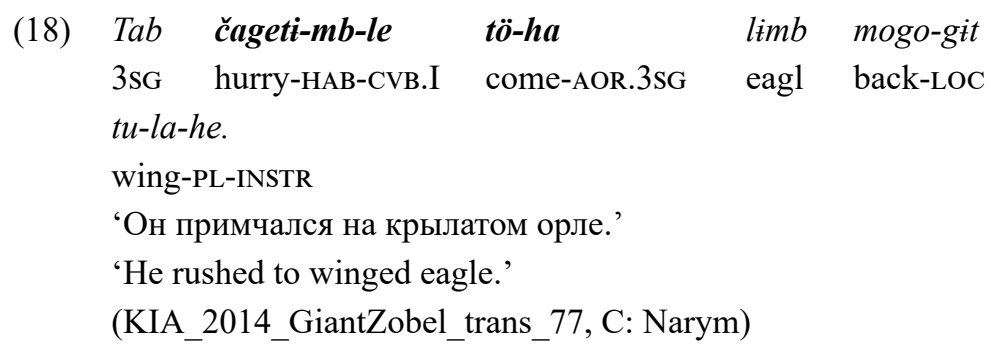

Table 5. Combinations of motion verbs in Central Selkup

\begin{tabular}{|c|c|}
\hline Converb & Finite verb \\
\hline čagд- 'hurry' & čaže- 'go' \\
\hline hokko- 'crawl' & $k \varepsilon n t i-$ 'sneak up' \\
\hline čagə- 'hurry’ & $t \overline{\ddot{O}}$ 'come' \\
\hline
\end{tabular}

There are just a few examples from Northern Selkup texts (Taz dialect). All pairings contain qan- 'go away' as the finite verb form, the converbs differ (see Table 6). In (19) the kind of movement is 'to jump', expressed by the converb pakti- and the path is 'to go away', expressed by the finite form of qan-.

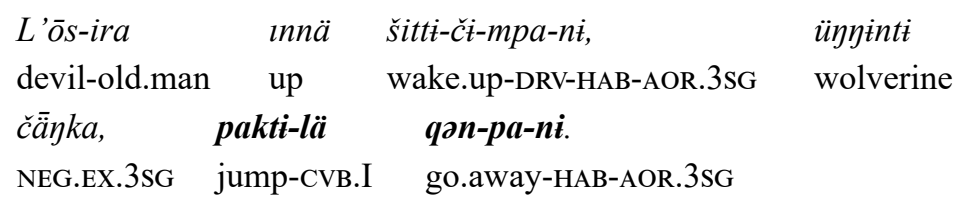
'Черт-старик проснулся - росомахи нет, прыгнувши ушла.'
'The devilish old man wakes up, the wolverine isn't there, it has hopped away.'
(MIV_1977_Icha_flk_52, N: Taz)


Table 6. Combinations of motion verbs in Northern Selkup

\begin{tabular}{lc}
\hline Converb & Finite verb \\
\hline$p \bar{u}$ - 'cross', poqqitti- 'settle.net', tōpiri-'berry', pakti- 'jump' & qən- 'go away' \\
\hline
\end{tabular}

\subsubsection{Type C}

Type $\mathrm{C}$ consists of a lexical verb in a converbal form and a semantically similar finite verb form. First analysis shows examples of five different speakers of the Ket' subdialects (Southern Selkup), as in (20a) to (20c). Furthermore there are two examples from the Southern dialect Middle $\mathrm{Ob}$ in (20d) and one example from the Northern dialect Taz in (20e). Examples of this type were not yet found in Central Selkup nor in Kamas (the closest related language to Selkup). Constructions differ in regard to the verbs which are used: it can be one and the same lexical verb $^{6}$ as püta- 'track down' in (20a) or semantically similar lexical verbs as kuča 'go to sleep' and qonda- 'sleep' in (20b), tšuka- 'worm' and tä- 'rot' in (20c), tita- 'walk' and t'iye- 'walk' in (20d) or qätti- 'beat' and sIl'l'alti- 'break down' in (20e).

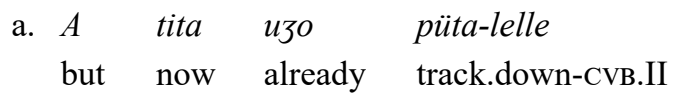
püta-lēenda-t
säp-qa-nde- $\eta$.
track.down-INCH-IPFV-3sG.O pocket-DIM-OBL.3sG-LOC.ADV
'А потом уже, нащупывая, нащупал, из кармана.'
'And then he feels his pocket.'
(SVG_1964_litekaPineweldju_flk_46, S: Upper Ket')
b. Awu-r-na-di, $\bar{t} r-a-d i \quad \boldsymbol{k u c ̌ a} a-l ' \boldsymbol{e}$
eat-FRQ-AOR-3DU.o drink-EP-3DU.o go.to.sleep-CVB.I
qonda-di.

sleep-3Du.o

'Они поели, попили и спать легли.'

'They eat, drink and go to sleep.'

(KMS_1966_TwoSisters_flk_42, S: Middle Ket')

\footnotetext{
6 The finite verb form is derived, the suffix $-l \bar{e}$ forms an inchoative aktionsart, but the meaning of the lexeme remains the same.
} 
c. Na sūrum wät't'e tšuka-r-l'e tä-mba,

this wild.animal meat worm-VBL-CVB.I rot-PST.REP.3sG

tšuka-m üt-man tādo-r-i-t $t$.

worm-ACC water-PROL bring-FRQ-EP-3SG.O

'Это зверя мясо, зачервивев, сгнило, червей по воде несет.'

'This meat of the animal got wormily rotted, it takes the worms through the water.'

(KNI_1964_ItjaCapeOfWorms_flk_69-70, S: Upper Ket')

d. Kut'e-t mat t'ije-ľse-špa-y t'itta-r-lä where-LOC.ADV 1sG walk-TR-IPFV-1sG.S walk-FRQ-CVB.I

tan naj man-nani watto-qey t'itta-r-lä

$2 \mathrm{SG}$ also $1 \mathrm{sG}-\mathrm{ADE}$ road-LOC walk-FRQ-CVB.I

t'̄̄ye-ľ̆ e-šp-le-nt.

walk-TR-IPFV-OPT-2SG

'Куда я шагаю (наступаю; по следам, наступая в следы), наступаю шагая, ты тоже по моим следам, шагая, наступай.'

'Where I walk, you will also walk along my path.'

(TFF_1967_ItjaAldigaPoenegesse_flk_6, S: Middle Ob)

e. Iča illä pall'-l'ä qütti-lä sil'l'alti-yi-ti.

Itja down jump-CVB beat-CVB.I break down-AOR-3sG.O

'Ича, вниз спустившись, ударив сломал (его).'

'Itja climbed down and slayed (him).'

(AVA_1973_Ichakicha2_flk_176, N: Taz)

\subsubsection{Type D}

Type D consists of a lexical verb in a converbial form and a finite verb which has undergone a grammaticalization process of semantic reduction and could act than as an auxilary while some meaning components may retain ${ }^{7}$. So in (21) the meanings of the auxiliary 'to sit' and of the converb 'to cry' are not in conflict with each other.

Klumpp (2005: 401) uses the term 'semantically reducible' instead of 'semantically reduced' to describe this issue. 


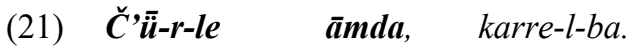 \\ cry-FRQ-CVB sit.3sG cry-INCH-PST.3SG \\ 'Плача, сидит горюет.' \\ 'She cries, cries out.' \\ (SAA_1971_MoleWifeVar_flk_34, C: Narym)}

Auxiliaries are inflected for different grammatical information such as tense, mood, person and number, while the converb expresses the semantic meaning and may be encoded for derivational suffixes. Auxiliaries in converbal constructions of type $\mathrm{D}$ will be divided here into initiotransformative, finaltransformative and nontransformative, following Johanson (1971) and Schönig (1984). Previous analyses show nine verbs which act as auxiliaries (cf. Table 7). In the interaction with the actional phrase (Sachverhalt in Sasse 1991), auxiliaries form different aktionsarten/(lexical) aspect meanings by emphasizing or eliminating boundaries (Phasenspezifizierung in Schönig 1984). These include durative, frequentative, iterative and habituative aktionsarten on the one hand, and ingressive, inchoative, egressive and resultative ones on the other hand.

Table 7. Auxiliaries in converbal constructions

\begin{tabular}{|c|c|c|}
\hline \multicolumn{2}{|c|}{ transformative } & \multirow{2}{*}{ nontransformative } \\
\hline initiotransform. & finaltransform. & \\
\hline qali- 'stay' & tādə- 'bring' & čā $\bar{z} \partial-' \mathrm{go}$ ' \\
\hline qwande- 'carry away' & omdz- 'sit down' & ippi- 'lie' \\
\hline \multirow[t]{2}{*}{$q(w) \partial n-'$ go away' } & & $\bar{a} m d \partial-/ \partial m d \partial-$ 'sit' \\
\hline & & $n \dot{t}-$ 'stand' \\
\hline
\end{tabular}

\section{qali- 'stay, remain'}

The initiotransformative verb qali- 'stay, remain' marks the left border of a an event, both with nontransfomative and initiotransformative actional phrases. There are several examples in Southern and Northern Selkup texts and in the mixed dialect. The examples from Southern (22a, b) and mixed (22c) dialects show qali- in stative situations with converbs of āmdi- 'sit' (22a), meše- 'be ill' (22b) and ora'hold' in (22c). In the Northern Selkup example from Taz (22d) qaliindicates a dynamic situation with the converb nitz- 'tear'. 
a. Pēk'k'e taw pil'eka-yən āmdi-l'e qali-y. hazel.grouse this side-LOC sit-CVB.I stay-3sG 'Рябчик на этой стороне, сидя остался.'

'The hazel grouse stays sitting on this side.' (KMS_1966_MouseGray_flk_28, S: Middle Ket')

b. Kalabokka meše-la-č-lä qāla i öl-tar-gālìy. Kalabokka ill-INCH-TR-CVB.I stay.3sG and head-hair-CAR 'Калабокка больным остался и без волос.'

'Kalabokka remains sick and without hair.' (TFF_1967_KolobokkaPoenegessa_flk_28, S: Middle Ob)

c. Čuečo-nd katte-d, čemn'a-n-d ol-n-da earth-ILL beat-3SG.o brother-GEN-3SG head-GEN-3sG laga-p ora-lbele kal-tte-d. heap-ACC hold-CVB.II stay-DRv-3sG.o

'He slams him onto the earth, grabs a part of the brother's head and keeps it.'

(NN_1855_Hero4_song_41-43, Mixed)

d. [...] n'oma-l' porqi-tí nitqille-lä qallē-n-ti. hare-ADJZ clothing-3SG tear-CVB.I stay-AOR-3sG.o

'[...] его заячья шуба порвавшись осталась (у них в руках).'

'[...] ripped up his leporine fur coat and held.' (KMP_1971_NyomalPorky_flk_35, N: Taz)

\section{qwande- 'carry away'}

There are two examples in the corpus using qwande- 'carry away' as auxiliary. Like qali- it marks the left border of a nontransfomative (23a), or of an initiotransformative (23b) event.

\footnotetext{
a. T'äptä t'äk köt-l'e qwända-ku-t. tale fast say-CVB.I carry.away-ITER-3sG.o 'Сказка быстро говорится.'

'The tale is quickly told.' (AGS_1968_FairytaleSnake_flk_47, S: Middle Ket')
} 
b. Mat ora-nna-p, pone čače-le

1sG hold-AOR-1sG.O outwards throw-CVB.I

kuanda-p, po-t par-o-nd čaps-a-p.

carry.away-1sG.o tree-GEN top-EP-ILL spear-EP-1sG.o

'I took her, throw her out on the street, put her on a tree.'

(NN_1855_Hero2_song_405-407, Mixed)

\section{$q(w) a n-$ 'go away'}

In two examples $q(w) \partial n$ - is used as an auxiliary. Both examples come from the Southern Selkup $\mathrm{Ob}$ dialect and resultative aktionsart is expressed. In (24a) the converb is formed from the telic intransitive verb qow - 'drown'. The auxiliary kon- 'go away', a variant of $q(w)$ on-, indicates that the boundary was crossed (resultative aktionsart). In (24b) qwat- 'go away' as a variant of qwan- occurs with the telic verb säl'sharpen'. The focus is here on leaving the situation that the converb describes.

a. Sado qiba n'ē qiba.n'e t'ari-y oj

two small daughter small.daughter say-3sG INTERJ

pazan'e $i$ qow-l'a kon-ni-y.

Baba-Yaga and drown-CVB.I go.away-AOR-3sG

'Ой, две дочки, ой, две дочки, баба-яга кричала, и потонула.'

'Two little daughters, little daughters, oops, Baba-Yaga says and drowns.'

(PMP_1961_ForestWoman_flk_168, S: Middle Ob)

b. $\bar{I}$-wə-t kibizo pawə-m $i \quad s a ̈ l-d-s \ddot{a}$

take-AOR-3SG.O small knife-ACC and grinder-3sG-INSTR

pō-qәn säl-lä qwat-ti-t.

stone-LOC sharpen-CVB.I go.away-DRV-3SG.o

'Взял маленький ножик и об точильный камень точить стал.'

'He takes a little knife and sharpens it with a grinder.'

(TFF_1967_KolobokkaPoenegessa_flk_10, S: Middle Ob)

\section{tādo- 'bring'}

The verb tādo- 'bring' is a finaltransformative auxiliary. With finaland nontransformative actional phrases it serves as a resultative marker as well and shows that the action is finished. In general the action 
is focused on a recipient and as a result the object is located at the recipient. $t \bar{a} d \partial-$ occurs in Central and Southern Selkup texts. In the Ket' subdialect it is only attested in translated texts from Russian, as in (25a). In all Southern examples $t \bar{a} d \partial$ in converbal constructions is used with the derivational suffix $-r$-, as in (25a) to (25c). ${ }^{8}$ In Central Selkup and the mixed dialect there are also examples without derivational marker, as in (26a) and (26b).
a. Täp qai-m-da=kka
tutto-l'l'e tādo-r-i-t,
$3 \mathrm{sG}$ what-ACC-INDEF $=\mathrm{EMPH}$
chew-CVB.I
carry-FRQ-EP-3SG.O
sättšim kwäi-no.
severely breath-AOR.3sG3
'Он что-то жует и тяжело дышит.'
'He is chewing something, breathing heavily.'
(KMS_1968_Burbot_trans_137, S: Middle Ket')
$\begin{array}{llllll}\text { b. A } & \text { nan } & \text { ugon } & \text { mazim } & \text { qwa-l'e } & \text { tādo-r-o-za-nt. } \\ \text { and } & \text { so } & \text { earlier } & \text { 1SG.ACC } & \text { beat-CVB } & \text { carry-FRQ-EP-PST-2SG }\end{array}$
'А как до этого ты меня бил!'
'But earlier, you beat me.'
(PMP_1961_BodylessHead_flk_111, S: Middle Ob)
c. İ'ä-n ald'วgə-t nā kätə-m kuddar
Itja-GEN grandmother-3SG this gut-ACC how

$\bar{e}-s \quad$ qwēs'e pel-le tädo-r-o-t.
be-PST.3sG backward put-CVB.I carry-FRQ-EP-3SG.O
'Itja's grandmother made the stomach as it has been before.'
(NN_1913_Itja_flk_71, S: Chaya)

(26)
a. Ör-le tatta-ut nedel kund.
drink-CVB.I bring-1PL week long
'Гулять начали всю неделю.'
'We celebrate the whole week.'

(SAI_1984_StoryAboutLifeLong_nar_27, C: Narym)

\footnotetext{
So far it is still not known how the - $r$ - works in these constructions. It cannot be a frequentative suffix because of the (final)transformative meaning of the action. It is likely that it could be a transitive suffix or maybe the original frequentative meaning is faded and only the form is still fixed.
} 
b. Oker madur waše-lebele tado-ga-mba ende-m one hero fly-CVB.II bring-ITER-PST.REP.3SG bow-ACC oran-ne-d. hold-AOR-3SG.O

'A hero rose up, took the bow.' (NN_1855_Hero2_song_138-141, Mixed)

\section{omdo- 'sit down'}

The second finaltransformative auxiliary is omdo- 'sit down'. Examples can be found in all dialectal groups except Central. Similar to other Samoyedic languages there ist a second lexeme ämdə-/omdə- 9 to express the atelic concept 'sit' (description below). Due to the lack of a written standard it is often difficult to distinguish both lexemes. Like $t \bar{a} d \partial$ - above, omdz- marks the right border and forms resultative readings if the actional phrase is final- or nontransformative, as in the $(27 \mathrm{a}-\mathrm{c})$.

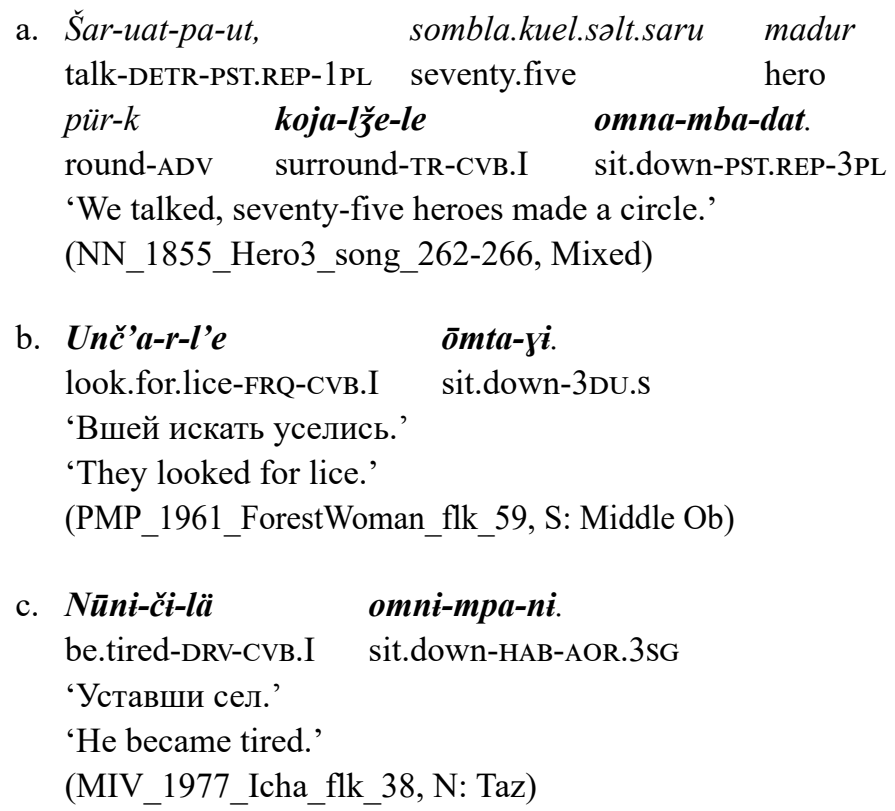

b. Unč'a-r-l'e

omta-yi.

look.for.lice-FRQ-CVB.I sit.down-3DU.s

'Вшей искать уселись.'

'They looked for lice.'

(PMP_1961_ForestWoman_flk_59, S: Middle Ob)

c. Nūni-či-lä omni-mpa-ni.

be.tired-DRV-CVB.I sit.down-HAB-AOR.3sG

'Уставши сел.'

'He became tired.'

(MIV_1977_Icha_flk_38, N: Taz)

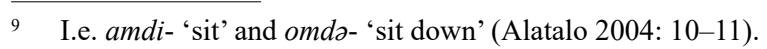


čă $\bar{\jmath}$ - 'go'

With all other nontransformative auxiliaries the function of the verb $\check{c} \bar{a} \bar{z}$ ว- 'go' is to mark an event as an unbounded situation. Examples can only be found in Southern Selkup (Ob and Ket' dialects), as in (28a, b) in which $\check{c} \bar{a}$ žz- is paired with oruw- 'grow up'.

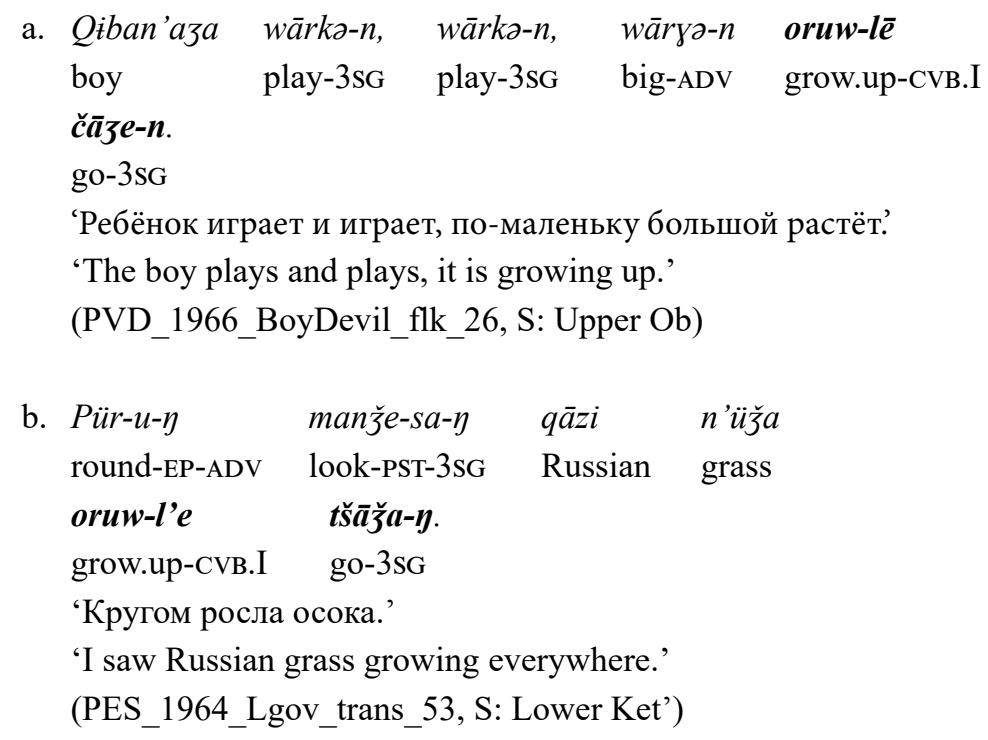

\section{ippi- 'lie'}

Like čā̧̌z- 'go' the verb ippi- 'lie' also acts as a nontransformative auxiliary and forms stative or serial readings. Different from Kamas, in Selkup ippi- is always nontransformative, the initiotransformative meaning 'lie down' is expressed by another lexem (pen-). It is not possible to clearly identify the function of ippi-because there is only one example in the corpus in which ippi-is used in a converbal construction. In (29a) from the Southern Ob dialect, ippi- is used in the (unmarked) present tense form and expresses the continuance of the action. On the one hand, since ill people do often lie, the meaning of ippi-could also be the literal one. On the other hand, the very similar example (29b) from Tatar, analyzed by Schönig (1984: 236) as an auxiliary construction, may well support the auxiliary character of $i p p i-$. More research is needed here to give a clear answer. 
(29)

a. $\bar{U} d \partial-m i n \quad t \bar{o}-w a-q \quad \bar{a} d^{\prime} a-t \quad i \quad \bar{a} w o-t$ evening-PROL come-AOR-3DU.S father-3sG and mother-3sG a Kalabokka meše-la-č-lä eppa $i$

but Kalabokka be.ill-INCH-TR-CVB.I lie.3sG and ol-tar-gālin. head-hair-CAR 'Вечером пришли отец его и мать, а Калабокка, болея, лежит и без волос.'

'In the evening his father and mother come and Kalabokka is lying around sick and without hair.'

(TFF_1967_KolobokkaPoenegessa_flk_29, S: Middle Ob)

b. Tatar (Schönig 1984: 236)

$\begin{array}{lll}\text { Abistay bik } \quad \text { awïrïp } & \text { yata. } \\ \text { woman.master very become.ill.CVB } & \text { lie } \\ \text { 'The old woman is very ill.' } & \end{array}$

\section{āmdo-/omdo- 'sit'}

The nontransformative verb āmdo-/omdo- 'sit' is the most frequent auxiliary in the corpus and can be found in all dialectal groups. It is the atelic counterpart to the finaltransformative auxiliary omdo- 'sit down' above. Different from the dynamic character of $c ̌ \bar{a}$ žz- 'go' in $(28 \mathrm{a}, \mathrm{b})$ above, āmdo-/omdo- is stative. The auxiliary always marks durative, frequentative, iterative or habituative aspect readings/aktionsarten. Similar as in Kamas it can be observed that amdo-/omdə- is used in situations that can really take place in a sitting position, such as the constructions with $\bar{c} \bar{u}$-/ $\check{c}^{\prime} \overline{\ddot{u}}$ - 'cry' in $(30 \mathrm{a}, \mathrm{b})$ or mirse- 'plane' in (30c).
a. $\partial m \dot{t}-t \dot{t}$
$\check{c} \bar{u}-r i-l \ddot{a}$
5mta-ni.
mother-3sG
cry-FRQ-CVB
sit-AOR.3SG
'Его мать плача сидит.'
'His mother cries.'
(MIV_1977_Icha_flk_64, N: Taz)

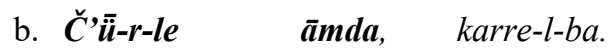
cry-FRQ-CVB.I sit.3sG cry-inch-PST.REP.3sG
'Плача, сидит горюет.'
'She cries, complains.'
(SAA_1971_MoleWifeVar_flk_34, C: Narym) 
$\begin{array}{llll}\text { c. Irra } & \text { qwändo-ga-j } & \text { mīrse-tši-lle } & \overline{\boldsymbol{a}} \boldsymbol{m} \boldsymbol{d a} . \\ \text { old.man } & \text { old-DIM-ADJZ } & \text { plane-TR-CVB } & \text { sit.3sG }\end{array}$

'Старик старый, строгая, сидит.'

'The old man planes.'

(KNI_1964_ItjaCapeOfWorms_flk_23, S: Upper Ket')

\section{$n i-$ 'stand'}

Similar to āmdo-/omdo- 'sit' and ippi- 'lie' the verb $n \dot{t}$ - 'stand' always has a stative meaning. The inchoative-stative meanings 'stand up', 'put' or 'stop' are expressed by the derived lexeme nile- 'stand up' or different lexems (utə-, malčə- 'stop', azi-, wazว- 'get up'). There is only one example in the corpus using $n \dot{i}$ - as an auxiliary (31). It is from the Central Selkup Vasyugan dialect and shows $n i$ - in the aorist form, paired with pudi- 'breath'.

$\begin{array}{lllll}N a \quad k o r g & a k o s ̌ k a-t & k o-n d i \quad t o-g a, & n i n d i \\ \text { whis bear } & \text { window-GEN } & \text { side-ILL come-AOR.3SG } & \text { here } \\ \text { pudi-le } & \text { ni-ya. } & & \\ \text { breath-CVв.I } & \text { stand-AOR.3SG } & \\ \text { 'Это медведь к окну подошел, здесь стоит, дышит.' }\end{array}$

'This bear comes to the side of the window, stands there breathing.'

(ChDN_1983_BearCameIntoVillage_nar_7, C: Vasyugan)

In the mixed Selkup dialect there are examples in which the telic verb nile- 'stand up' is used. In these examples it is paired with the intransitive verb tō- 'come', as in (32). According to Klumpp's description for Kamas (Klumpp 2005a: 405, 2005b: 19), nìle- here has a mirative function. A formal equivalent can be found in the Turkish -(V)p turur (cf. Johanson 2000: 72).

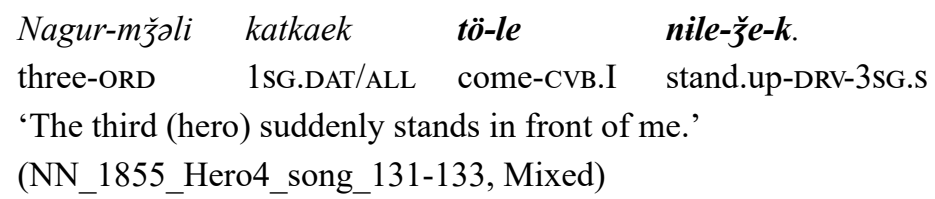




\section{Conclusions}

Starting from the observation that there are much more examples of converbal constructions of the type converb + finite verb in Southern Selkup than in other Selkup dialect groups, the present study was designed to provide an overview of different types of converbal constructions in the Selkup dialect groups Northern, mixed, Central, and Southern on the basis of the Selkup Language Corpus. The converbal constructions have been divided on a preliminary basis into four groups A-D. The classification of type $\mathrm{D}$ is oriented to analogous constructions in Tatar (Schönig 1984) and Kamas (Klumpp 2002). It can be observerd that some lexical verbs in converbal constructions may have undergone a grammaticalization process (Figure 1 below) and developed into auxiliaries to different degrees.

lexical verb $>$ aspectual auxiliary $>$ aspectual suffix

Figure 1. Grammaticalization path ${ }^{10}$.

Different phasal verbs are part of converbal constructions of type A (3.1.1). Similar to transformative auxiliaries (qali- 'stay', qwand $\varepsilon$ 'carry away', $q(w) \partial n$ - 'go away', tädo- 'bring', omdo- 'sit down') they express the beginning or the end of an action. In contrast to the latter, phasal verbs do not specify the phase structure of the converb construction they are contained in (Schönig 1984: 269). Only the beginning of an action is expressed. It remains to be examined whether and which of the phasal verbs with the meaning 'to finish' could be a finaltransformative auxiliary as in Mari and Tatar (Bradley 2016a, Schönig 1984).

Converbal constructions expressing complex motions belong to type B (3.1.2). They occur in all dialectal groups: Southern (16), mixed (17a, b), Central (18) and Northern (19). The converb expresses the manner of movement, the finite verb form refers to the path of the action and so modifies the converbal meaning. It should be further discussed whether the semantic meaning of finite verbs belonging to type B also is somewhat bleached and whether they actually are on the

10 The grammaticalization of lexical verbs as auxiliaries has been extensively studied cross-linguistically, e.g. Heine/Kutcheva (2002). 
grammaticalization path above, namely between the first (lexical verb) and the second stage (auxiliary).

There are some special converbal constructions in Type C, where the actional phrase is emphasized by consisting of identical (20a) or similar (20b-e) lexemes in the converbal form and in the finite verb form. The examination of further language data may specify this type more precisely.

Verbs of the fourth type D are at the second stage of the grammaticalization path above. They serve as auxiliaries to express different (lexical) aspect meanings. Following Johanson (1971) and Schönig (1984) they can be further subdivided into initiotransformative, finaltransformative and nontransformative auxiliaries (Table 7 in 3.1.4). Auxiliaries are semantically reduced but a part of the original meaning can be preserved. The function of auxiliaries is to mark durative, frequentative, iterative or habituative aktionsarten (non-transformative verbs čă̌̌z- 'go', ippi- 'lie', ammdo-/omdo- 'sit' and ni- 'stand') on the one hand, and ingressive, inchoative (initiotransformative verb qali-

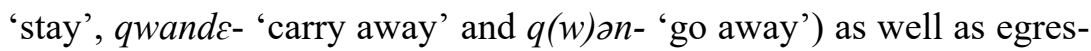
sive and resultative aktionsarten (finaltransformative verbs $t \bar{a} d \partial-$ 'bring' and omdo- 'sit down') on the other hand.

It becomes apparent from Table 8 that most auxiliaries appear in one of the Southern Selkup dialects. As there are similar converbal constructions (atypical for Uralic languages) in Kamas, Mari and Udmurt that have developed under Turkic language contact (Khakas for Kamas, Chuvash for Mari, Tatar for Udmurt), it could be expected that there is also a Turkic influence on Selkup converbal constructions of type D.

Table 8. Distribution of auxiliaries in Selkup dialects

\begin{tabular}{lcccc}
\hline & Northern & Central & mixed & Southern \\
\hline initiotransformative & & & & \\
\hline qali- 'stay' & + & & + & + \\
qwande- 'carry away' & & + & & + \\
$q(w) \partial n$ - 'go away' & & & & + \\
\hline finaltransformative & & & & \\
\hline tãdo- 'bring' & + & + & + \\
omdo- 'sit down' & & + & + \\
\hline
\end{tabular}




\begin{tabular}{|c|c|c|c|c|}
\hline & Northern & Central & mixed & Southern \\
\hline \multicolumn{5}{|l|}{ nontransformative } \\
\hline čā̧̌ž- 'go' & + & & & + \\
\hline ippi- 'lie' & + & + & & + \\
\hline āmdə-/smdə- 'sit' & + & & & + \\
\hline$n \dot{t}$ - 'stand' & & + & + & \\
\hline
\end{tabular}

Southern Selkup dialects (and especially Ket' dialects) were in contact with Chulym, a Turkic language (Tuchkova and Kuznetsova 2010). In the Chulym example (33) the finite verb kän- 'send' is already merged with the converb čättig- 'choke' and thus on the way to become an aspectual suffix (the last stage of the grammaticalization process). The Turkic-Selkup language contact might be one explanation for the different frequencies of using converbal constructions within the Selkup dialectals groups.

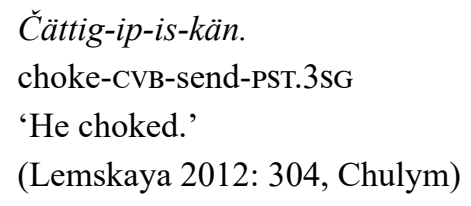

Čättig-ip-is-kän. choke-CVB-send-PST.3SG

'He choked.'

(Lemskaya 2012: 304, Chulym)

Different from Kamas, two lexemes can be distinguished in Selkup to express 'sit' and 'sit down'. Both verbs act as auxiliaries, āmdo-/ omdz- 'sit' as nontransformative, omdz- 'sit down' as initiotransformative. The nontransformative auxiliary ippi- 'lie' has no telic cognate. Here other lexems are used to express the meaning 'lie down'.

Because analyses just have started, the statements about the current status of Selkup converbal constructions as well as the classification of verbs using as auxiliaries are preliminary. Furthermore, a look at additional Selkup language data as well as similar constructions in other Samoyed (Nenets, Enets, Nganasan, Kamas) and in contact languages (for example Chulym) might provide new insights. 


\author{
Address \\ Dr. Anja Behnke \\ Institute of Finno-Ugric and Uralic Studies (IFUU) \\ Überseering 35, Postfach \#29 \\ D-22297 Hamburg \\ Germany \\ E-mail: anja.behnke@uni-hamburg.de
}

\begin{abstract}
Abbreviations
$\mathrm{ADE}$ - adessive, AOR - aorist, CAR - caritive, CVBI - simple converb, CVBII - complex converb, DAT/ALL - dative/allative, DETR - detransitive, DIM - diminutive, DRV - derivation, EMPH - emphatic, EP - epenthetic vowel, FRQ - frequentative, GEN - genitive, HAB - habituative, ILL - illative, INCH - inchoative, INDEF - indefinite, INSTR - instrumental, INT.PF - intensive perfective, INTERJ - interjection, IPF - imperfective, IPFV - imperfective verbal, ITER - iterative, LOC.ADV - locative adverbial, NEG - negative particle, NEG.EX - negative existencial verb, o - objective conjugation, OPT - optative, ORD - ordinal number, PROL - prolative, PST.REP - past reportative, $\mathrm{S}$ - subjective conjugation, VBL - verbalizer
\end{abstract}

\title{
References
}

Bradley, Jeremy (2016a) Mari converb constructions: productivity and regional variance. $\mathrm{PhD}$ thesis. Universität Wien.

Bradley, Jeremy (2016b) "Verb-Framed Motion Events in Uralic". Finnisch-Ugrische Forschungen 63, 126-152.

Budzisch, Josefina, Anja Harder, and Beáta Wagner-Nagy (2019) Selkup language corpus. Version 0.1. Archived in Hamburger Zentrum für Sprachkorpora.

Čeremisina, Maria I. and E. Martynova (1991) Sel'kupskij glagol. Formy i ix sintaktičeskie funkcii. Novosibirsk.

Décsy, Gyula (1966) Yurak Chrestomathy. (Indiana University Publications: Uralic and Altaic Series, 50.) Bloomington: Indiana University Press.

Fil'chenko, Andrej J. (2010) Aspects of the grammar of Eastern Khanty. Tomsk.

Gluškov, Sergej V. and Aleksandra V. Bajdak (2016) "O dialektnoj prinadležnosti četyrex geroičeskix pesen’ M. A. Kastrena”. Linguistica Uralica 4, 282-288. 
Haspelmath, Martin (1995) “The converb as a cross-linguistically valid category". In Martin Haspelmath and Ekkehard König, eds. Converbs in cross-linguistic perspective. Vol. 13, 1-55. Mouton de Gruyter: Berlin and New York.

Haspelmath, Martin (1999) “Converb”. In K. Brown and J. Miller, eds. Concise encyclopedia of grammatical categories, 110-115. Amsterdam: Elsevier.

Heine, Bernd and Tanja Kutcheva (2002) World lexicon of grammaticalization. Cambridge: Cambridge University Press.

Helimski, Eugene (1983) The language of the first Selkup books. Szeged.

Helimski, Eugene (1998) "Selkup". In Daniel Abondolo, ed. The Uralic languages, 480-515. London: Routlegde.

Horváth, Laura (2013) "On the aspectual markers of the Udmurt language - expressions of aspects in dialects”. In Márta Csepregi, Kata Kubínyi, and Jari Sivonen, eds. Grammatika és kontextus - új szempontok az uráli nyelvek kutatásában III, 108-123. Finnugor Tanszék, Eötvös Loránd Tudományegyetem, Budapest.

Isanbaev, Nikolaj I. (1978) “Obščee i otličitel'noe v sostavnyx glagolax marijskogo i povolžsko-tjurkskix jazykov”. Voprosy marijskogo jazyka, 59-90. Joškar-Ola.

Johanson, Lars (1971) Aspekt im Türkischen. Uppsala.

Johanson, Lars (2000) “Turkic indirectives". In Östen Dahl, ed. Evidentials: Turkic, Iranian and Neighbouring languages, 61-87. Mouton de Gruyter: Berlin and New York.

Kel'makov, Valentin K. (1975) "Sparennye glagoly v udmurtskom jazyke - na materiale kukmorskogo dialekta”. In: Voprosy udmurtskogo jazykoznanija - sbornik statej, 90-105. Udmurskij NII istorii èkonomiki, literatury i jazyka pri Sovete Ministrov Udmurtskoj ASSR. Izhevsk.

König, Ekkehard (1995) “The meaning of converb constructions". In M. Haspelmath and E. König Converbs in cross-linguistic perspective. Vol. 13, 57-95. Mouton de Gruyter: Berlin and New York.

Katzschmann, Michael (2008) Chrestomathia Nganasanica. Norderstedt.

Klumpp, Gerson (2002) Konverbkonstruktionen im Kamassischen. Wiesbaden: Harrassowitz.

Klumpp, Gerson (2005) “Aspect markers grammaticalized from verbs in Kamas”. Acta Linguistica Hungarica 52, 4, 397-409. https://doi.org/10.1556/ALing.52.2005.4.4

Kuznecova, Ariadna I., Evgenij Xelimskij, and Elena V. Gruškina (1980) Očerki po sel'kupskomu jazyku tazovskij dialekt. Vol. 1. Moskva: Nauka.

Kuznecova, Natal'ja G. (1995) Grammatičeskie kategorii južnosel'kupskogo glagola. Tomsk: Izd. Tomskogo Universiteta.

Lemskaya, V. (2012) "A Chulym Turkic text. Handsome-brown". In Andrej J. Fil'chenko, ed. Annotated folk texts of Ob-Yenissei area. Vol. V-2, 184-237. Tomsk.

Nedjalkov, V. (1995) "Some typological parameters of converbs". In Martin Haspelmath and Ekkehard König, eds. Converbs in cross-linguistic perspective. Vol. 13, 97-136. Mouton de Gruyter: Berlin and New York.

Pischlöger, Christian (2000) "Hilfsverbverbindungen in einigen uralischen und nichturalischen Sprachen”. In T. Seilenthal, ed. Congressus Nonus Internationalis Fenno-Ugristarum 7.-13.8.2000. Pars IV: Dissertationes sectionum: linguistica 1, 45-52. Tartu. 
Ramstedt, Gustav J. (1903) Über die Konjugation des Khalka-Mongolischen. (Mémoires de la Société Finno-Ougrienne, 19.) Helsinki: Société Finno-Ougrienne.

Sasse, Hans-Jürgen (1991) “Aspekttheorie“. In Arbeitspapiere des Instituts für Sprachwissenschaft der Universität zu Köln. NF 14, 1-35. Köln.

Schönig, Claus (1984) Hilfverben im Tatarischen. Untersuchungen zur Funktionsweise einiger Hilfsverbverbindungen. Wiesbaden: Steiner.

Siegl, Florian (2013) Materials on Forest Enets, an indigenous language of Northern Siberia. (Mémoires de la Société Finno-Ougrienne, 267.) Helsinki: SUS.

Talmy, Leonard (2007) "Lexical typologies". In Timothy Shopen, ed. Language typology and syntactic description. Vol. 3: Grammatical categories and the lexicon, 66-168. 2nd ed. Cambridge: Cambridge University Press.

Tereščenko, Natal'ja M. (1979) Nganasanskij jazyk. Leningrad: Nauka.

Tikkanen, B. (2001) “Converbs”. In M. Haspelmath Handbücher zur Sprach- und Kommunikations-wissenschaft: Sprachtypologie und sprachliche Universalien. Vol. 20, Halbb. 2, 1112- 1123. Berlin and New York: De Gruyter Mouton.

Tuchkova, Natal'ja A. and Natal'ja G. Kuznecova (2010) "Die Südselkupen und die südlichen Grenze ihres Verbreitungsgebietes”. Finnisch-Ugrische Mitteilungen 32-33, 595-605.

Valijärvi, Riitta-Liisa (2008) "Converbs in Northern Selkup". In E. J. Vajda, ed. Subordination and coordination strategies in North Asian languages, 167-177. Amsterdam and Philadelphia: John Benjamins Publishing.

Voevodina, N. M. (1976) "Funkcii deeprichastij i deeprichastnyx oborotov v predlozhenii sel'kupskogo jazyka". In Jazyki i toponimi. Vol. 1, 92-102. Tomsk.

Winkler, Eberhard (2011) Udmurtische Grammatik. (Veröffentlichungen der Societas Uralo-Altaica, 81.) Harrassowitz: Wiesbaden.

Kokkuvõte. Anja Behnke: Konverbitarindid sölkupi keeles. Sölkupi keeles kasutatakse konverbe ja konverbitarindeid laialdaselt paljudes erinevates süntaktilistes funktsioonides. Siiski näitavad korpuseandmed märkimisväärseid esinemissageduse erinevusi sölkupi murrete lõikes (põhja-, kesk- ja lõunasölkupi). Lõuna-sölkupi murdes esinevad konverbitarindid enam kui kolm korda sagedamini kui kesk- ja põhja-sölkupi murretes. Sarnast põhja-lõuna vastandust on näha ka mõningate nende funktsioonide puhul, eriti liitpredikaatide puhul. Tekib küsimus, millest on selline esinemissageduste erinevus tingitud ja millised strateegiad vastavad kesk- ja põhja-sölkupi murretes lõunasölkupi konverbitarinditele.

Märksõnad: konverbitarindid, liitpredikaat, lõuna-sölkupi, kesk-sölkupi, põhja-sölkupi, korpus, turgi keelekontakt 


\begin{abstract}
Аннотация. Аня Бенке: Деепричастные конструкции в селькупском языке. В селькупском языке деепричастия и деепричастные конструкции широко используются в самых разных синтаксических позициях. Однако корпусные данные показывают значительные различия в частотности их употребления в разных диалектных группах (северной, центральной и южной). В южноселькупском конструкции с деепричастиями встречаются более чем в три раза чаще, чем в центральном и северном. Такое же разделение между севером и югом можно наблюдать и на примере некоторых функций, в особенности сложных предикатов. В этой связи возникают вопросы о причинах такой разницы в частотности и о том, какие стратегии используются в северном и центральном селькупском для выражения значений, которые в южноселькупском выражаются конструкциями с деепричастиями.
\end{abstract}

Ключевые слова: деепричастные конструкции, сложные предикаты, южноселькупский язык, центральноселькупский язык, северноселькупский язык, корпус, контакты с тюркскими языками 